\title{
PRELUDE TO TANZANIA'S 2010 GENERAL ELECTIONS: REFLECTIONS AND INFLECTIONS ${ }^{1}$
}

\author{
Benson A Bana
}

\author{
Dr Benson A Bana is Senior Lecturer and Head of the Department of \\ Political Science and Public Administration at the University of Dar es Salaam \\ e-mail: bana@udsm.ac.tz
}

\begin{abstract}
Managing elections in transitional countries, of which Tanzania is one, is not an easy task. Poorly managed elections are sources of tension and conflicts. This article takes stock of the preparations for the 2010 general elections in Tanzania, drawing lessons from other elections held since the country reverted to competitive multiparty elections. Although the electoral machinery has been reviewed and adjusted to make it more efficacious there are a number of unresolved problems that may dent the forthcoming elections. These include the limitations of the first-past-the-post electoral system; the prohibition of independent candidature; the disallowing of voting in the diaspora; ambiguities in the registration requirements, especially in Zanzibar; ineffective voter education interventions; and the undesirable role of the shehas ${ }^{2}$ (Zanzibar) and district and regional commissioners in electoral processes. The newly enacted legislation aimed at controlling the use of money and deterring corruption in Union elections is a good measure for ensuring fair play. However, the enforcement strategies and mechanisms are still weak. Enactment of the law is one thing, but its effective enforcement is another issue. This article examines the efficacy of political parties on the road to the 2010 elections and, in light of empirical and anecdotal data, reveals systemic and endemic weaknesses in opposition parties that pave the way for landslide victories for the ruling party and its president.
\end{abstract}

1 The author is grateful to the anonymous reviewer for critical but incisive and constructive feedback.

2 A sheha is a central government administrator appointed by the regional commissioner to oversee the implementation of central government laws, orders, policies and directives at grassroots level. 


\section{INTRODUCTION}

Elections are a critical element in a democracy and for the attainment of democratic governance in a polity. They provide the means through which those aspiring to lead, and their political parties, are given a mandate to lead the government for a specific period of time. Elections are also processes through which the electorate expresses its diverse interests in and support for the parties and candidates. Elections are means by which leaders and sometimes public policies are chosen by the people simply because they involve a choice between candidates or a choice about whether or not a particular policy is to be followed. An election is a formal act of collective political decision-making. Moreover, elections are the major, if not the only formalised mechanisms through which individual citizens and political parties play an active role in politics. In a much wider sense, elections put governments in power and remove them from power. Therefore, elections are considered essential to the enhancement of democracy since they allow citizens to participate actively in politics and provide an opportunity to elect legitimate political leaders.

This article provides a preliminary formative analysis of the Tanzanian general elections, to be held on 31 October 2010. The analysis is largely informed by the current state of politics in Tanzania as well as the empirical findings of opinion polls conducted in the country. In order to situate the forthcoming elections in their proper context we draw on lessons of the past about the conduct of competitive elections in the country.

We are convinced that in order to understand the present and to be able to predict the future with some precision and accuracy we need historical facts. History is our prologue to the analysis of political events, including general elections.

Secondly, we explore and examine the legal framework and institutional arrangements that have been put in place to govern the management and conduct of the 2010 general elections. We are aware that elections are not carried out in a vacuum. They are governed by the electoral machinery, including legislation and electoral bodies created to facilitate the management of elections in a polity. They set the conditions under which elections are conducted and define the 'dos and don'ts' of the electoral process in order to prevent anarchy, taking into account that elections are not only fun events but are also 'clumsy instruments' (Powell 2000, p 6). In other words, we set out to answer the first fundamental question: 'How well is the government of Tanzania prepared to ensure the smooth running of the 2010 general elections as well as to attain a credible, free and fair election?'

Thirdly, we focus on the political behaviour of key participants in the electoral processes as the country approaches the elections. The key question to inform our 
assessment is: 'To what extent and in what manner have the key actors, including political parties, repositioned themselves to enhance their competitive edge in the forthcoming elections.

Fourthly, we examine available and current indicators in order to enable us to give an informed opinion and make predictions about the 2010 general election results.

\section{TANZANIA'S GENERAL ELECTIONS: HISTORICAL ANTECEDENTS}

Elections are not a new phenomenon in Tanzania. The October 2010 general elections will be the country's tenth since the mainland (then Tanganyika) attained independence in 1961. At independence, both the Tanzanian mainland and Zanzibar had multiparty political systems with parliamentary sovereignty, largely autonomous civil society organisations and competitive elections. The first multiparty elections were held on the mainland a year after independence, in 1962. In Zanzibar multiparty elections were held before the January 1964 revolution.

The first-generation nationalist leaders opted for a monopolistic one-party system, abandoning political pluralism and the Westminster model of governance. In 1965, Tanzania became a de jure single-party country. The political leadership claimed that a multiparty system was divisive and undermined important nationbuilding efforts.

The Tanganyika African National Union (TANU) on the mainland and the Afro-Shiraz Party (ASP) in Zanzibar became the sole articulators and aggregators of interests. In 1977 the two parties merged to form a single party, Chama Cha Mapinduzi (CCM), whose supremacy was enshrined in the 1977 Constitution of the United Republic of Tanzania. All government functions, including the management of general elections, were carried out under the auspices of this party, which was the ultimate authority in the country, as was clearly stated in Articles 3 and 10 of the Constitution (TEMCO 2001).

\section{ELECTIONS UNDER A ONE-PARTY SYSTEM: LESSONS OF EXPERIENCE}

Four elements must be pointed out. Firstly, in 30 years (1965-1995) of conducting elections under the one-party system no general election was skipped in Tanzania. And despite the monopolistic nature of the electoral processes voters were given a chance to choose between two party-screened candidates for Parliament and for councils. As a result, the rate of elite circulation in Parliament as a result of voter choice was, in some cases, much higher than that in many well-established democracies (TEMCO 2001; Cliffe1967; Othman, Bavu \& Okema 1990; Mukandala \& Othman 1985). 
Secondly, precedents for peaceful leadership change at the national level were established under the one-party system, which meant that Tanzanians were used to such changes before the advent of multipartyism. ${ }^{3}$ Thirdly, a basis for national unity and political tranquillity had been built under the one-party system by controlling the rise of divisive forces in the polity. The national consensus under one-party rule provided a conduit for transition to competitive politics. Fourthly, there was anecdotal and empirical evidence that the one-party system in Tanzania enjoyed a reasonable level of legitimacy, even at the height of the campaigns for political pluralism (Baregu \& Mushi 1994; URT 1991). This was an important asset for Tanzania, paving the way for peaceful political transition and a move towards plural politics.

There were many shortcomings that had adverse effects on general elections. The presidential elections were acutely undemocratic, offering no choice at all, being on the Yes/No system. The anti-democratic, monopolistic political culture penetrated all institutions, including civil society organisations (CSOs) and government machinery and institutions, including the public service. Even today the ruling CCM is somewhat unwilling to learn to share power with other political actors. During elections the party invests heavily to win all seats, leaving no space for opposing parties. There is a long way to go to change the monolithic and monopolistic orientation and political behaviour of the ruling party.

Thirdly, the one-party system led to the underdevelopment of politics and political institutions in Tanzania through the banning or controlling of previously autonomous CSOs and political organisations, including political parties. The political parties that had been created following the re-introduction of the multiparty system were inexperienced and under resourced, and had very little penetration into the public, especially at grassroots level. It is likely that it will take time to build viable competitive political parties in Tanzania. The one-party system undermined the basic human rights that are such an important ingredient in democracy-building and consolidation. Even today the Constitution does not permit independent candidates to stand in elections. This means that the new pluralist system inherited an erroneous constitution suited to a monolithic system (Luoga 1995).

Fourthly, there has not been a significant political transformation. Using the civic culture model developed by Almond \& Verba (1963) one could argue convincingly that when Tanzania changed to a multiparty political system in 1992, the 'parochial-subject' political culture rather than the desirable 'participant

3 In 1972 Aboud Jumbe was peacefully installed as president of Zanzibar after the assassination of the incumbent, President Aman Abeid Karume. Ali Hassan Mwinyi replaced Jumbe, who was impeached by the CCM's National Executive Committee, and President Julius Nyerere was also peacefully replaced when he voluntarily decided to step aside. 
political culture' was the dominant characteristic of the majority of Tanzanians. It seems plausible that 'parochial' and 'subject' cultures pave the way inadequately for the electorate to engage in general elections as informed and responsible citizens. In such a situation, elections are unlikely to enable citizens to influence and control policymakers.

\section{COMPETITIVE ELECTIONS IN THE POLITICAL PLURALISM ERA}

\section{The 1995 general elections}

The first competitive multiparty general elections were held in 1995, beginning with the election of the president of Zanzibar and members of the House of Representative. The Union elections came later. In Zanzibar there was stiff competition between the CCM candidate (Dr Salmin Amour) and the secretary general of the newly formed Civic United Front (CUF - Seif Sharif Hamad). Table 1 shows the votes each candidate obtained.

Table 1

1995 Presidential election results

\begin{tabular}{|l|l|c|c|}
\hline \multicolumn{1}{|c|}{ Candidates } & \multicolumn{1}{c|}{ Party } & Votes obtained & Percentage \\
\hline CHEYO, John Momose & UDP & 258734 & 4.0 \\
\hline LIPUMBA, Ibrahim Haruna & CUF & 419873 & 6.4 \\
\hline MKAPA, Benjamin William & CCM & 4026422 & 61.8 \\
\hline MREMA, Augustin Lyatonga & NCCR-Mageuzi & 1808616 & 27.8 \\
\hline Total & & 6513645 & 100 \\
\hline
\end{tabular}

Source: National Electoral Commission

UDP United Democratic Party; CUF Civic United Front; CCM Chama Cha Mapinduzi; NCCR-Mageuzi National Convention for Construction and Reform-Mageuzi

The official estimate of the number of voters was 11047 478: 10688551 on the Mainland and 358927 in Zanzibar. The number of registered voters was 8855127 (80.2 \%), including 353916 (95.8\%) in Zanzibar and 8511311 (79.6\%) on the Mainland. Thirteen parties nominated candidates for the parliamentary elections. The number of votes won by each party is shown in Table 2 . 
Table 2

1995 Parliamentary election results

\begin{tabular}{|l|c|c|c|}
\hline Party & Votes obtained & Percentage & Number of seats \\
\hline CCM & 314206 & 59.22 & 219 \\
\hline CHADEMA & 396825 & 6.16 & 4 \\
\hline CUF & 323432 & 5.02 & 19 \\
\hline NCCR-Mageuzi & 1406343 & 21.83 & 0 \\
\hline NLD & 26666 & 0.41 & 0 \\
\hline NRA & 60707 & 0.94 & 0 \\
\hline PONA & 18155 & 0.28 & 0 \\
\hline TADEA & 76636 & 1.19 & 0 \\
\hline TLP & 27963 & 0.43 & 4 \\
\hline TPP & 15335 & 0.24 & 0 \\
\hline UDP & 213547 & 3.32 & 0 \\
\hline UMD & 41257 & 0.64 & 274 \\
\hline UPDP & 19841 & 0.31 & 100 \\
\hline Total & 6440913 & & 0 \\
\hline
\end{tabular}

Source: National Electoral Commission

CHADEMA Chama cha Demokrasia na Maendeleo; NLD National League for Democracy; NRA National Reconstruction Alliance; PONA Popular National Party; TADEA Tanzania Democratic Alliance; TLP Tanzania Labour Party; TPP Tanzania People's Party; UMD Union for Multiparty Democracy; UPDP United People's Democratic Party

The 'winner-takes-all' or 'first-past-the-post' system was not the best option for Tanzania's general elections. The need to introduce a proportional representation (PR) system was inescapable in order to enhance representation in Parliament.

The 1995 elections were beset with administrative and logistical problems, including a shortage of election materials, inadequate security for election materials, inadequate competence of election personnel, a lack of or inadequate voter education, administrative errors leading to the failure to vote, and the lack of a permanent voters' register.

Moreover, the ruling party, the CCM, was accused of misusing the advantages of incumbency, especially by using state instruments and resources. Unethical conduct, a lack of respect for election rules and undemocratic practices within the parties were all cited as stumbling blocks to the smooth running of the elections. Taking into account all these circumstances, a credible consortium of 
local observers, the Tanzania Election Monitoring Committee (TEMCO) concluded that the 1995 general elections in Tanzania were 'free but not fair'. ${ }^{4}$

\section{The 2000 general elections}

Prior to the 2000 elections, some of the articles of the Constitution and sections of the Local Government Authorities (Elections) Act 1979 and the Elections Act 1985 were amended.

Firstly, the head of the National Electoral Commission was to be a judge of the Court of Appeal or the High Court. This enabled the institutions responsible for the management of elections to be controlled by people with impeccable integrity.

Secondly, the law barred employment for top public servants who sought political office, and banned members of the armed forces from becoming members of political parties.

Thirdly, the amendment enhanced the participation of women in politics by raising the number of special seats for women (previously fixed at 15 per cent) to reach 20-30 per cent of all other parliamentary seats.

The procurement of election materials and tendering processes were adversely affected by the fact that donors failed to honour their funding commitments and did not disperse the money on time. Table 3 shows the pledges / commitments and actual funds released by donors to the National Electoral Commission (NEC).

Table 3

Donors' financial pledges and actual disbursement of funds to the NEC

\begin{tabular}{|l|r|r|r|}
\hline Donors & \multicolumn{1}{|c|}{$\begin{array}{c}\text { Pledges } \\
\text { TSh }\end{array}$} & $\begin{array}{c}\text { Actual amounts } \\
\text { released (TSh) }\end{array}$ & \multicolumn{1}{c|}{\begin{tabular}{c}
\multicolumn{1}{c|}{ Variations } \\
TSh
\end{tabular}} \\
\hline Donor Basket Group & 3200000000 & 3140668800 & -59331200 \\
\hline European Union & 4042164000 & 923875000 & -3118289000 \\
\hline USAID & 87808000 & 29763100 & -58044900 \\
\hline Government of Denmark & 1284312800 & 1618584000 & 332271200 \\
\hline Government of Japan & 48480000 & 4880000 & 0 \\
\hline Government of China & & 6000000 & 600000 \\
\hline Total & 8662764800 & 5767370900 & 2797383900 \\
\hline
\end{tabular}

Source: National Electoral Commission

4 TEMCO had six certificates for elections, as follows: 'Clean Free and Fair'; 'Qualified Free and Fair'; 'Free but not Fair'; 'Unfree and Unfair'; 'Totally Mismanaged' and 'Aborted'. 
During the 2000 elections the law did not assign the responsibility for conducting civic education to any institution. Civic education, including voter education, was provided voluntarily by CSOs, using donor funds. Both civic and voter education were underfunded and failed to comply with the cardinal principle of facilitating learning for adults. Donors refused to finance education through publicly owned media. The result of all these factors was that voter education came late and was inadequate.

In Zanzibar several severe problems undermined the electoral process. For example, much of the Zanzibar Urban West region did not vote because of a lack of voting materials. Consequently, the Zanzibar Electoral Commission (ZEC) cancelled elections in all 16 constituencies in the region. The ZEC also stopped the vote counting process in Pemba and parts of Unguja. The tendency of the ZEC to make decisions unilaterally suggested a serious lack of political prudence. In Pemba, ballot boxes were forcibly seized by police against the will of party agents and sent to places that were inaccessible. Election observers and monitors reported incidents of the use by the state of excessive force. For example, it was reported that:

These CUF supporters - men and women, young and old - were beaten up most mercilessly and handed in a manner which, to an observer, would suggest that the state instruments of law and order were carrying out vengeance on them rather than performing ordinary arrests. ${ }^{5}$

Moreover, throughout the electoral process, and especially during the campaign period, opposition parties complained about state organs that, in their eyes, consistently acted in favour of the ruling party, while disrupting the political activities of opposing parties. Furthermore, the voter registration process was dominated by charges and counter charges that some who were not entitled to vote were being registered while others, who were entitled to vote, were denied registration. The ZEC refused or failed to release an authoritative figure of eligible voters for the Isles, suggesting that the registration process was neither transparent nor competent.

In the presidential elections the CUF, the major opposition party in the Isles, refused to recognise the victory of the CCM or the presidency of Amani Karume. Opposing parties boycotted the rescheduled elections in 16 constituencies of the Urban West Region, arguing that fresh elections should be held in all of Zanzibar. The situation culminated in violence in January 2001, resulting in 20 riot-related 
deaths. The electoral process in Zanzibar was marred by grave irregularities, to the extent that TEMCO considered the elections to have been aborted. It reported:

The abortion was in the making from the beginning of the registration, was carried through to the campaigns marked by Police harassment, and culminated on $29^{\text {th }}$ October, 2000, in the shambles of the 16 constituencies of the Urban West region, and the illegal halt to the counting of votes in the other constituencies.

TEMCO 2001, p 199

To reiterate, there was acute disregard for the legislation governing elections and acceptable conventional parameters of free and fair elections. The ZEC flouted its own laws.

\section{The 2005 general elections}

The 1995 and 2000 general elections provided useful lessons for the National Electoral Commission, the government and other stakeholders involved in organising the 2005 elections. The shortcomings had to be avoided. The quest for more effective management of elections was compelling and triggered the need for the amendment of several pieces of legislation governing the conduct of elections in Tanzania. ${ }^{6}$ The amendments largely took into account the recommendations of the NEC on almost all the steps of the electoral process. Thirty-three amendments to the electoral laws were effected in time to facilitate the smooth running of the 2005 elections. This showed the commitment of the government and the political leadership to addressing the problems that were experienced in 1995 and 2000, as well as to the principles of free and fair elections.

It is imperative to note that the law does not yet empower the NEC to register all eligible voters in Zanzibar. The commission is required to use the voters' register prepared by the ZEC, thus the NEC does not have the names of voters all over the country in the permanent national voters' register (PNVR), which contains the records of voters in all constituencies and wards on the Mainland.

The cost of establishing the PNVR was TSh30-billion, given to the NEC by the government of Tanzania and by donors, who contributed US\$9.53-million. The total spent on the 2005 general elections was TSh62.53-billion, of which the government gave the NEC TSh58.7-billion and donors TSh3.53-billion. ${ }^{7}$

6 These were the Elections Act, 1985 (Act 1 of 1985) and the Local Authorities (Elections) Act, 1979 (Act 4 of 1979).

7 See NEC Report on the 2005 Presidential, Parliamentary and Councillors' Elections, pp 14-15. The exchange rate of the US $\$$ to the TSh is US $\$ 1=$ TSh 1,155.884. 
The NEC registered 15919749 (7 800677 male and 8119072 female) voters of 16578466 estimated voters, equivalent to 96.03 per cent of the target (NEC 2006, p 36). Moreover, 15744 voters were registered in Zanzibar ${ }^{8}$ and the ZEC registered 507164 . Ten of the 18 political parties nominated candidates for the presidential and vice-presidential elections, a contrast with the 1995 and 2000 elections when only four parties had nominated presidential candidates. One presidential candidate was female and three women were nominated to stand as running mates - a step towards redressing the gender imbalance in Tanzania's electoral politics.

The 2005 general elections were distinguished from previous elections by a wider choice, both within the ruling party and across the other parties. Most of the opposition parties fielded candidates who had stood in previous elections, including Freeman Mbowe of CHADEMA, Augustine Mrema of the TLP, John Cheyo of the UDP and Ibrahim Lipumba of CUF for the union presidency, and Seif Sharif Hamad of CUF in Zanzibar. Table 4 shows the presidential election results for each political party.

Table 4

2005 Presidential election results

\begin{tabular}{|l|l|r|c|}
\hline Candidates & Party & $\begin{array}{c}\text { Votes } \\
\text { obtained }\end{array}$ & Percentage \\
\hline Jakaya Mrisho Kikwete & CCM & 9123952 & 80.28 \\
\hline Prof Ibrahim Haruna Lipumba & CUF & 1327125 & 11.68 \\
\hline Feeman Aikaeli Mbowe & CHADEMA & 668756 & 5.88 \\
\hline Augustine Lyatonga Mrema & TLP & 84901 & 0.75 \\
\hline Edmund Sengondo Mvungi & NCCR-MAGEUZI & 55819 & 0.49 \\
\hline Mchungaji Christopher Mtikila & DP & 31083 & 0.27 \\
\hline Dr Emmanuel John Makaidi & NLD & 21574 & 0.19 \\
\hline Anna Claudia Senkoro & PPT-MAENDELEO & 18783 & 0.17 \\
\hline Prof Leonard Kanangwe Shayo & MAKINI & 17070 & 0.15 \\
\hline Paul Henry Kyara & SAU & 16414 & 0.14 \\
\hline Total & & 11365477 & 100 \\
\hline
\end{tabular}

Source: National Electoral Commission

PPT-MAENDELEO Progressive Party of Tanzania-Maendeleo; SAU Sauti ya Umma

8 These voters were qualified to vote for the president of the United Republic of Tanzania only. 
As the statistical data in Table 4 show, the candidate for the ruling CCM achieved a landslide victory. Opposition parties won a total of 2241525 votes, equivalent to 19.72 per cent of valid votes. The performance of the parties in the opposition camp was somewhat dismal, taking into account that they had been in politics for about 13 years, giving rise to questions about their efficacy in preparing their supporters and members for elections.

Table 5

2005 Parliamentary election results

\begin{tabular}{|c|c|c|c|c|}
\hline Political Party & $\begin{array}{l}\text { Number of } \\
\text { candidates }\end{array}$ & $\begin{array}{c}\text { Votes } \\
\text { obtained }\end{array}$ & Percentage & $\begin{array}{l}\text { No of seats } \\
\text { won }\end{array}$ \\
\hline CCM & 232 & 7579897 & 69.66 & 206 \\
\hline CHADEMA & 144 & 888133 & 8.16 & 5 \\
\hline CHAUSTA & 61 & 38085 & 0.35 & 0 \\
\hline CUF & 213 & 1542254 & 14.22 & 19 \\
\hline DP & 45 & 11876 & 0.11 & 0 \\
\hline FORD & 11 & 1685 & 0.01 & 0 \\
\hline JAHAZI ASILIA & 55 & 21042 & 0.19 & 0 \\
\hline MAKINI & 16 & 2102 & 0.02 & 0 \\
\hline NCCR-MAGEUZI & 71 & 339452 & 2.2 & 0 \\
\hline NLD & 29 & 6054 & 0.06 & 0 \\
\hline NRA & 27 & 3459 & 0.03 & 0 \\
\hline PPT-MAENDELEO & 16 & 13532 & 0.12 & 0 \\
\hline SAU & 52 & 6085 & 0.06 & 0 \\
\hline TADEA & 34 & 6845 & 0.06 & 0 \\
\hline TLP & 115 & 306219 & 2.81 & 1 \\
\hline UDP & 38 & 155887 & 1.43 & 1 \\
\hline UMD & 21 & 1510 & 0.01 & 0 \\
\hline UPDP & 42 & 5456 & 0.05 & 0 \\
\hline Total & 1222 & 10829513 & 100 & 232 \\
\hline
\end{tabular}


As shown in Table 5, the incumbent party won the parliamentary elections, acquiring 88.79 per cent of the constituency seats against a total of 11.21 per cent (26 seats) for the opposition. Thirteen parties did not win a seat. The CCM won 69.66 per cent of the total votes in the parliamentary election, but obtained 88.79 percent of all constituency seats in Parliament. This suggests the need to consider electoral reform in order to replace the winner-takes-all system with PR. Moreover, a one-party dominated legislature does not accord well with the imperatives of pluralist politics, and particularly a multiparty political system.

Unlike the previous elections, the 2005 elections were observed and monitored by 16 groups, including three local observer groups and 13 foreign observer groups. The observers were satisfied with the competence of the NEC in the management of the elections. Most election officials, parties, candidates and voters enforced and complied with the electoral rules and peace reigned during campaign meetings. Only minimal and non-intentional election management discrepancies were noted, and election officials resolved most of these. In contrast with the previous elections state instruments of law and order (the police) and state media dealt with all parties fairly and more equitably (TEMCO 2006, p 176).

The above pluses were accompanied by a few minuses. Firstly, the CCM was accused of spending state resources for its own campaign, contrary to the law, and it used its incumbency unfairly. Secondly, resource inequalities among the parties made the election a race among unequals. Thirdly, candidature in Tanzania is legally tied to membership of and sponsorship by a political party. Independent candidature is not allowed. This restriction has been debated since the country reverted to a multiparty political system in 1992 and it continues to be debated. Fourthly, the nomination of candidates by some political parties, excluding, to a great extent, the CCM, CHADEMA and CUF was not conducted competitively and transparently. The smaller and newer parties resorted to a system of 'hand-picking' candidates, constraining the chances of poor aspirants. Fifthly, the legalisation of the house-to-house campaigns and offering of 'traditional hospitality', locally known as 'Takrima', paved the way for corruption. Illiteracy limited the voters' capacity to exercise free choice at a large number of polling stations, more so in Zanzibar than on the mainland. The rate of spoilt votes was relatively high, at 5.4 per cent, and primarily due to illiteracy and poor voter education.

In the light of the above TEMCO awarded the 2005 general elections a 'Clean Certificate of Free and Fair Elections'. The observers concluded that 'the observed shortcomings were insignificant and could not alter the election results' (TEMCO 2006, p 177), making the 2005 general elections broadly credible and legitimate.

In Zanzibar, the ZEC estimated that it would register 548124 voters but only managed to register 499007 - 91 per cent of the target. Six parties, namely the CCM, CUF, Democratic Party (DP), JAHAZI Asilia, NRA and SAU nominated 
candidates for the presidential elections, compared with only two parties in the 1995 and 2000 elections. A total of 451229 valid votes (97.91\%) were cast in the presidential election, while 9619 votes $(2.09 \%)$ were spoiled.

Election observers reported that ZEC personnel were more competent in managing the elections than they had been in 1995 and 2000. The ZEC and a few CSOs facilitated voter education programmes and the media and political parties contributed to civic and voter education. The CCM-CUF 'Muafaka' ${ }^{9}$ of October 2001 helped bring consensus on the electoral rules in Zanzibar, and led to important changes in the Zanzibar Constitution and electoral law.

There were changes in the composition of the ZEC; the residency rule enabled the preparation of the permanent voter register, which was used for the first time in 2005. The opposition parties, especially the CUF, were more satisfied with the electoral rules and arrangements for the 2005 elections. All stages of the elections in Zanzibar were heavily policed, much more so than those on the Mainland. This was because Zanzibar was known to be highly conflict-prone during elections (REDET-TEMCO 2006, p 177). Voter registration was significant and the number of candidates standing in Zanzibar was higher in 2005 than it was in 1995 and 2000.

However, there were still shortcomings in the 2005 elections. Firstly, as in 1995 and 2000, in 2005 state media in Zanzibar continued to give more attention to the electoral activities of the ruling party than to those of opposition parties. The regional and district commissioners and the shehas were partisan in favour of the ruling party, mobilising voters on behalf of the CCM, facilitating the campaigns of CCM candidates and, in most cases, using state resources, leading to violations of election procedures.

There were significant inequalities in the resources available to the various political parties. Only the CCM and CUF enjoyed state subsidies, other parties did not have sufficient resources to run their electoral machinery effectively. The legal prohibition of independent candidates was a major constraint that infringed the political rights of individuals; incidents of intimidation were reported and opposition parties were denied access to grounds claimed to belong to the CCM. Gender imbalance remained high - of the six people who contested the Zanzibari presidential election only one was a woman. A lack of transparency in tallying presidential votes, which was done behind closed doors at the ZEC offices, increased mistrust and suspicion that the presidential election results may have been manipulated. The two CUF commissioners on the electoral body rejected the results, which gave Amani Karume the victory, on the grounds that they had not been involved in the vote tallying process.

9 'Muafaka' is a Kiswahili concept/word denoting agreement or consensus. 
The major opposition party, the CUF, did not concede defeat and, consequently, did not recognise the victory of the CCM candidate. This resulted in a political impasse in the Isles until, in November, President Amani Karume (CCM) and Secretary General Seif Sharif Hamadi (CUF) reached consensus, popularly known as ' Maridhiano'. Generally, the trend in elections in Zanzibar may be summarised as follows:

Zanzibar has historically been a difficult place to get election results which can be judged reliable and legitimate by stakeholders particularly defeated parties. No major party has conceded defeat since 1957. In this kind of political ecology, the above shortcomings will create doubts and suspicion ...'

REDET-TEMCO 2006, p 127

In light of the past, we are now in a position to examine the October 2010 general elections. It is to this that we now turn.

\section{PRELIMINARY ASSESSMENT OF THE 2010 GENERAL ELECTIONS}

Both the NEC and the ZEC have embarked on preparations for the 2010 general elections. The two commissions have registered new voters and have updated the PNVR. According to the NEC only 19670631 of the targeted 22210187 (about $88.6 \%$ ) eligible voters will be able to vote in the election. Initially there were 21210187 registered voters, but 1539556 (about 7.2\%) have been struck off the register for various reasons, including death. ${ }^{10}$ NEC deleted 243631 who died between 2005 and 2010; it disqualified 214125 who registered more than once, while 765236 were removed from the register because of contradicting transfer information; forms for 290002 were not found and another 15873 did not meet the criteria for registration. It is incomprehensible to disenfranchise eligible voters on the grounds of 'missing forms'. In Zanzibar 44125 Zanzibaris are eligible to vote in the Union elections only (NEC 2010). A total of 55000 polling stations will be created, compared to 47000 in 2005 . On average, each polling station will cater for 385 voters.

By May the ZEC had registered 407669 voters compared to 499007 registered in 2005. ${ }^{11}$ The ZEC's director of elections argued that opportunities to cheat had been eliminated in the voter registration process, an argument that generated

10 The statistical information was released to members of the press by the NEC's Director of Elections, Mr Rajabu Kiravu, on 16 August 2010. See also The Citizen, Tuesday 17 August 2010, p 1.

11 This is the official figure released by the Zanzibar Electoral Commission (ZEC). The figure is available at: referendum.zec.go.tz/ResultsManagement/PublicReports/ResultsReports.aspx 
more heat than light. It is expected that the number of voters will increase to match population growth. There has been no event in Zanzibar to cause negative population growth or a decelerated population growth rate. The variation in voter registration numbers seems to suggest that in previous elections the cheating windows were left open, either by default or by design.

The CUF has already raised concerns about the voter registration and voter register updating processes. The party claims that about 15000 Zanzibaris who are eligible voters (in constituencies which have already collected statistical data) have not been recorded in the permanent voter register and are likely to be disenfranchised (Mwananchi 10 May 2010, p 2). This allegation is too critical to be ignored, taking into account the volatile nature of electoral politics in the Isles. The Revolutionary Government of Zanzibar, and particularly the ZEC, have a duty to ensure that legally qualified people are registered. The ZEC should facilitate the registration of voters who experienced difficulties and delays in obtaining their Zanzibar identification cards, a prerequisite for being registered to vote.

\section{Election timetables}

The NEC's nomination day was 19 August and campaigns are scheduled to begin on 20 August and end on 30 October. The ZEC set 10-30 August as the period for the nomination of presidential candidates, 15-30 August for the nomination of House of Representatives candidates and 10 September-30 October for campaigns.

The election management bodies have definite election plans and a timely release of the election timetables enables political parties and key players, including election observers, to plan for their roles and activities in the elections.

\section{THE LEGAL FRAMEWORK}

\section{Electoral law}

Elections are governed by an acceptable legal framework and their legitimacy, freeness, and fairness hinges on fair laws. The Government of the United Republic of Tanzania, on the advice of the NEC, has reviewed the legal framework governing the conduct of general elections in the country. Two laws have been passed by Parliament - the Electoral Laws (Miscellaneous Amendments) Act, 2009, which includes changes to both the Elections Act, 1985 and the Local Government (Elections) Act, 1979; and the Election Expenses Act, 2010. The Electoral Laws (Miscellaneous Amendments) Act provides, among a range of 
technical amendments, for updating the PNVR twice between general elections and for the nomination of women for special seats. It also establishes a code of conduct for political parties as a statutory instrument. In 2008 the Zanzibar Electoral Commission issued regulations for updating the PNVR prior to the elections.

\section{Election Expenses Act, 2010}

The Election Expenses Act was passed by the National Assembly of the United Republic of Tanzania on 11 February 2010 and accepted by the president on 17 April 2010. The law aims to regulate and control the use of funds and curb illegal practices in the electoral process, including nomination, campaigning and voting, specifically in regard to gift giving and donations. Tanzania becomes the first country in Africa to have this kind of legislation.

It has been reported that 'in 2005, allegations of corruption in elections were widespread, with allegations that the funds scooped from the Bank of Tanzania's (BoT) External Payment Account (EPA) were spent on elections by one political party' (Daily News, 4 May 2010, p 9). According to a recent report, the local government elections held in October 2009 were also marred by corruption and vote buying (LHRC 2010). We do not have the authority to dispute the findings; however, generalisation exaggerates the magnitude of the problem.

\section{Provisions in the new Election Expenses legislation}

The Election Expenses legislation, inter alia, defines the powers of the registrar of political parties in the enforcement of the law, including the dos and don'ts, as shown in Table 6.

Table 6

Provisions in the Election Expenses Act, 2010

\begin{tabular}{|l|l|}
\hline Provision & \multicolumn{1}{c|}{ Legislative prerequisites } \\
\hline Section 4 & $\begin{array}{l}\text { Confers on the registrar of political parties the power to supervise } \\
\text { and administer election expenses }\end{array}$ \\
\hline Section 5-(1) & $\begin{array}{l}\text { Empowers the registrar to examine the financial records of a } \\
\text { candidate or political party and to demand information related to } \\
\text { election expenses of a political party or candidate }\end{array}$ \\
\hline Section 8-(1) & $\begin{array}{l}\text { Obliges each political party to conduct and fund its election } \\
\text { campaign by utilising its own funds from the sources stipulated in } \\
\text { the Political Parties Act }\end{array}$ \\
\hline
\end{tabular}




\begin{tabular}{|c|c|}
\hline Section 9-(1) & $\begin{array}{l}\text { Requires candidates to disclose at least seven days before the } \\
\text { nomination day the amount of funds they have in their possession } \\
\text { and expect to receive and spend on the elections }\end{array}$ \\
\hline Section 9-(2) & $\begin{array}{l}\text { Obliges every political party which participates in any election } \\
\text { to disclose to the registrar of political parties within } 30 \text { days after } \\
\text { the nomination day all funds which it intends to use as election } \\
\text { expenses and to use for its candidates as election expenses }\end{array}$ \\
\hline Section 10-(1) & $\begin{array}{l}\text { Mandates the minister responsible for political parties to prescribe } \\
\text { the maximum amount of election expenses depending on the } \\
\text { difference in the size of electoral constituency, categories of } \\
\text { candidates, population and communication infrastructure. The } \\
\text { minister is also empowered to vary the amount of election expenses } \\
\text { to be used by political parties during election campaigns }\end{array}$ \\
\hline Section 1-(1) & $\begin{array}{l}\text { Compels candidates or political party to report to the registrar the } \\
\text { funds used in excess of the prescribed limit, giving reasons for the } \\
\text { use of excess funds }\end{array}$ \\
\hline Section 11-(2) & $\begin{array}{l}\text { Requires each political party to ensure that all donations received in } \\
\text { the form of money are deposited in the special account opened by } \\
\text { the party for election expenses and election expenses shall be paid } \\
\text { from that account }\end{array}$ \\
\hline Section 11-(4) & $\begin{array}{l}\text { Requires political parties to disclose voluntary donations received } \\
\text { from any individual or organisation, in and outside the United } \\
\text { Republic of Tanzania }\end{array}$ \\
\hline Section 12-(1) & Stringently restricts foreign funding for election expenses \\
\hline Section 13-(1) & $\begin{array}{l}\text { Compels every candidate, political party, non-governmental } \\
\text { organisation, faith based organisation and community based } \\
\text { organisation that participates in election activities to keep records } \\
\text { of funds, names and the postal, physical and electronic addresses of } \\
\text { donors }\end{array}$ \\
\hline Section 15-(1) & $\begin{array}{l}\text { Compels non-governmental organisations, faith based organisations } \\
\text { and community based organisations to disclose sources and the } \\
\text { amount of funds to be used for advocacy or public awareness for } \\
\text { the furtherance of election campaigns }\end{array}$ \\
\hline Section 16 & $\begin{array}{l}\text { Requires all expenses and payments made in respect of elections to } \\
\text { be vouched, billed and validly receipted }\end{array}$ \\
\hline $\begin{array}{l}\text { Section } 18-(3-4) \\
\text { Section } 19-(4)\end{array}$ & $\begin{array}{l}\text { Requires mandatory auditing of accounts and submission of } \\
\text { audited accounts to the registrar of political parties }\end{array}$ \\
\hline $\begin{array}{l}\text { Section } 21-(1)(a-g) \\
\text { Section } 22\end{array}$ & $\begin{array}{l}\text { Prohibits unfair conducts, including corruption and any } \\
\text { inducement whatsoever of voters }\end{array}$ \\
\hline Section 23-(1) & $\begin{array}{l}\text { Illegalises or criminalises unconscionable funding, including } \\
\text { payment or the provision of food or drinks or the entertainment of } \\
\text { voters }\end{array}$ \\
\hline Section 28-(1) & $\begin{array}{l}\text { Gives presidential candidates the right to utilise the government } \\
\text { broadcasting service and television during the election campaign }\end{array}$ \\
\hline
\end{tabular}


Despite the good intentions of the law, it contains some provisions that have been at the centre of criticism. The Act vests in the registrar of political parties, who is a political appointee, excessive power in election matters, thus making the registrar the 'alpha and omega' in the implementation of the law. She/ he is player, referee, and judge. The law appears to permit the registrar to usurp the powers of the electoral commission and the judiciary, a potential source of controversy, confusion, and chaos during the elections. The office of the registrar does not have the technical capacity and resources required to ensure effective enforcement of the new law in the entire United Republic of Tanzania.

The criteria to be used by the minister responsible for political parties to set a ceiling on the amount of money to be spent by parties and candidates is a further source of controversy, taking into account the instability of Tanzania's currency.

The prohibition on receiving money from within or outside the country 90 days before the general elections is another serious area of contention.

Sceptics believe the Act, like many other pieces of legislation, will be just another paper tiger.

In Zanzibar there has been no effort to amend the existing principal election law. It seems the elections in the Isles will be held under the existing law, which is the Elections Act No 11, 1984. However, the electoral regulations have been amended subject to approval by the relevant authority. The proposed amendments include new provisions relating to the inspection of the permanent voter register; the Code of Conduct for Local and International Observers and the Code of Conduct for Political Parties. The ZEC announced in May that fees will be reduced from TSh3-million to TSh2-million for presidential candidates and TSh200 000 for candidates for the House of Representatives. Nomination fees for people aspiring to become councillors have also been reduced, from TSh50 000 to TSh30 000. This will make it easier for members of smaller parties and candidates with limited budgets to exercise their right to stand as candidates (ESP 2010, p 1).

\section{Financial resources}

Elections are at the heart of democracy, but they are expensive undertakings, particularly for poor countries such as Tanzania. The smooth running of the electoral process presupposes the availability of adequate funds. For the 2010 elections the National Electoral Commission has budgeted TSh64-billion (about US\$47.1-million) that the Government of the United Republic of Tanzania must make available to the commission, while the government has approved TSh60.2billion (NEC 2010), about 97.2 per cent of the NEC's total budget. Development partners (donors) have also pledged to finance the elections. Table 7 shows the pledges and status of the development partners' financial commitments. 


\section{Table 7}

\section{Development partners' financial commitments and status}

\begin{tabular}{|c|c|c|c|c|}
\hline $\begin{array}{l}\text { Contributors } \\
\text { to Basket } \\
\text { Fund }\end{array}$ & Pledged/signed & $\begin{array}{c}\text { Pledged/signed } \\
\text { (USD) }\end{array}$ & $\begin{array}{l}\text { Disbursed } \\
\text { (USD) }\end{array}$ & Status \\
\hline Canada & CAD \$1000 000 & $\$ 919117$ & $\$ 983284$ & Signed \\
\hline Denmark & DKK5 000000 & $\$ 995778$ & $\$ 995778$ & Signed \\
\hline $\mathrm{EC}$ & Euro2 700000 & $\$ 3620759$ & 0 & Signed \\
\hline Finland & Euro2 000000 & $\$ 2839409$ & $\$ 2839409$ & Signed \\
\hline Netherlands & Euro1 000000 & $\$ 1219512$ & 0 & Pledged \\
\hline Norway & USD1 000000 & $\$ 1000000$ & 0 & Pledged \\
\hline Sweden & SEK43000 000 & $\$ 6151645$ & $\$ 6151645$ & Signed \\
\hline Switzerland & USD 1000000 & $\$ 1000000$ & $\$ 1000000$ & Signed \\
\hline UNDP & USD1 000000 & $\$ 1000000$ & $\$ 1000000$ & Signed \\
\hline UK / DFID & GBE6 000000 & $\$ 9222256$ & $\$ 6148171$ & $\begin{array}{l}£ 4 \mathrm{~m} \text { Signed } \\
£ 2 \mathrm{~m} \text { Pledged }\end{array}$ \\
\hline Total & & $\$ 27968469$ & $\$ 19118287$ & \\
\hline
\end{tabular}

Source: Lehner 2010

In terms of financing the 2010 elections it seems that if all pledges are honoured and government disburses the amount required by the NEC the problem of under funding will be circumvented.

\section{Voter education}

The amended election legislation vests in the NEC the authority to provide and regulate voter education. The NEC has prepared a strategic plan and guidelines for those interested in providing voter education (Kiravu 2010, p 7). In spite of these efforts both the NEC and the government lack a comprehensive civic education strategy of which voter education is a part. A piecemeal approach is not appropriate.

While it is a good idea to extend voter education during the election season it would be better to ensure that a sustainable strategy for civic education is in place. We do not have evidence yet to demonstrate that the NEC's strategy for 
facilitating voter education for the 2010 elections will be significantly different from that in 2005. Educators must be aware of the learning needs of voters and appropriate methods of facilitating voter education learning packages and have a sound knowledge of voter psychology and behaviour.

Drawing on the experience of 2005 it seems that most providers of voter education in Tanzania, including the CSOs, do not have the skills to facilitate meaningful learning. Unfortunately, donors are reluctant to finance government institutions, which do have the required expertise and experience. The electoral management bodies, the NEC and the ZEC, do not have the capacity necessary to supervise and regulate voter educators. Moreover, political parties in the country are devoting scant attention either to civic education or to voter education for their members and supporters. An inadequately informed electorate is unlikely to make rational and educated choices.

\section{Unresolved electoral issues}

Five major issues remain unresolved as Tanzania prepares for the elections. The first is the prohibition on independent candidates, a law that is, by all standards, obnoxious and that undermines democratic practice. In the Tanzanian system a candidate belongs more to his/her party than to the voters (REDET-TEMCO 2006, p 124). This anomaly not only infringes the individual's political and civic rights, it also limits and narrows the choices of the electorate. Progressive segments of society, including academics and human rights activists, have called for independent candidates to be permitted, but support from political parties and government is relatively weak. The issue is currently before the Court of Appeal, whose verdict, should it declare the ban unconstitutional, may have serious consequences for the preparations for the 2010 elections.

The second issue is conflicting interpretations of the voter registration laws in Zanzibar. The law states that a person will be considered a resident eligible to register to vote in a constituency if she/he has a permanent residence in the area or has been employed there for three years. In the registration process the interpretation of the requirement of residency has been very controversial. In many areas the narrow view of residence in a location for three years as a condition for registration has purposely been privileged over other conditions. The CUF has frequently complained that the CCM has used it as a means of disenfranchising CUF supporters (REDET-TEMCO 2006, p 25). The qualification leaves room for abuse and manipulation. Zanzibar is preparing for the 2010 elections without revisiting this issue.

Thirdly, neither the electoral laws of the Union nor those of Zanzibar provide for Tanzanians living outside the country to vote. Both the NEC and the ZEC, 
as well as other key players, are silent about the need to extend voting rights to expatriate Tanzanians. This exclusion, too, conflicts with the cardinal principles of democracy and is another issue that is not being tackled in the run-up to the elections.

The fourth problem is that the country enters the 2010 election season without clear boundaries between the statutory responsibilities and political obligations of the regional commissioners (RCs), district commissioners (DCs) and shehas (in Zanzibar). Holders of these positions are politicised public servants appointed by the presidents on the basis of demonstrated loyalty to the ruling party. As such they are cadres and staunch supporters of the ruling party. They cannot refrain from acting in a partisan way during elections. Experience shows that they mobilise voters on behalf of the ruling party and facilitate the campaigns of the ruling party using state resources, including vehicles and security personnel. In 2005 they even intervened very directly in registration and campaign processes. Tanzania enters the 2010 general election season with this systemic problem that should have been addressed to the satisfaction of all stakeholders in order to have a levelled political terrain for the elections.

The fifth unresolved issue is the number of preferential seats for women. The government's commitment is to attain a 50-50 gender representation in Parliament. In the current Parliament 92 of 307 members (about 30\%) are women. Taking into account the historical facts, including limited access to educational opportunities as well as under representation in decision-making, the need to attain gender balance is inescapable if democratic governance is to be realised in Tanzania. The 'fast track' approach to gender balance - suddenly increasing special seats for women from 30 to 50 per cent - is not the best strategy for the country or for democracy. Experience has shown that elite women in urban settings will get more seats than poor rural women. Gradual and deliberate strategies are required to empower women through competitive elections in constituencies.

\section{READINESS OF POLITICAL PARTIES FOR THE ELECTIONS}

Political parties need to make the necessary preparations in order to win the confidence and trust of the electorate. They are expected to recruit candidates for various positions, prepare election manifestos, deliver civic and voter education, prepare their supporters and members to participate in the electoral process, and canvass votes using legally acceptable means.

Anecdotal evidence reveals concerted and serious efforts on the part of the ruling party, the CCM, to prepare for the forthcoming elections. The party has initiated fundraising projects and has a comprehensive budget - it plans to spend about TSh50-billion on the election. More people are publicly declaring their 
intention of standing on CCM tickets than are expressing their intention to contest elections under the auspices of opposition parties. However, the preparations of opposition parties generally seem to lack serious vigour. Anecdotal evidence reveals that most opposition political parties in Tanzania have weak organisational and leadership capacity and are short on both human and financial resources.

\section{ELECTION INDICATORS: WHO GETS WHAT?}

\section{Opinion polls}

Opinion polls carried out by two independent organisations, SYNOVATE (whose poll was carried out in November 2009) and Research and Education for Democracy in Tanzania (REDET - whose poll was carried out in March 2010) ${ }^{12}$ show that the CCM still has a significant lead over the opposition parties.

\section{Table 8}

\section{Poll results}

$\mathrm{N}$ (the number of targeted respondents) $=2600$

\begin{tabular}{|c|c|c|c|}
\hline Parties & President & MPs & Councillors \\
\hline $\mathrm{CCM}$ & $1997(77.2 \%)$ & $1756(68.0 \%)$ & $1759(68.2 \%)$ \\
\hline CUF & $237(9.2 \%)$ & $263(102 \%)$ & $273(10.6 \%)$ \\
\hline CHADEMA & $109(4.2 \%)$ & $221(8.6 \%)$ & $198(7.7 \%)$ \\
\hline TLP & $4(0.2 \%)$ & $5(0.2 \%)$ & $5(0.2 \%)$ \\
\hline NCCR-MAGEUZI & $4(0.2 \%)$ & $7(0.3 \%)$ & $5(0.2 \%)$ \\
\hline $\mathrm{CCJ}$ & $1(0 \%)$ & $2(0.1 \%)$ & $2(0.1 \%)$ \\
\hline UDP & $1(0 \%)$ & $1(0 \%)$ & $1(0 \%)$ \\
\hline SAU & $0(0 \%)$ & $0(0 \%)$ & $0(0 \%)$ \\
\hline JAHAZI ASILIA & $1(0 \%)$ & $3(0.1 \%)$ & $3(0.1 \%)$ \\
\hline CHAUSTA & $1(0 \%)$ & $1(0 \%)$ & $1(0 \%)$ \\
\hline DEMOKRASIA MAKINI & $1(0 \%)$ & - & - \\
\hline FORD & $1(0 \%)$ & - & - \\
\hline HESITANT/UNDECIDED & $224(8.7 \%)$ & $315(12.2 \%)$ & $328(12.7 \%)$ \\
\hline Total & $2586(100 \%)$ & $2581(100 \%)$ & $2581(100 \%)$ \\
\hline
\end{tabular}

Source: REDET 2010

FORD Forum for the Restoration of Democracy; CCJ Chama cha Jamii

12 REDET is the most credible and professional political research organisation in Tanzania. Its opinion polls and predictions have, on all occasions, proved reliable in relation to the election results. 
The unpopularity of opposition parties among voters is a phenomenon in Tanzania - the CCM, with its long history, including having fought for independence and having led the country since independence in 1961, has not lost its lead in the opinion polls or in general elections since the advent of multiparty elections in 1995. Both young and old members of the electorate may have acquired what the voting theorists/behaviourists refer to as 'party identification' behaviour, revealing that:

When an election comes along, there is an interaction between a voter's long-term identification and various short-term influences, such as current political issues, campaign events, the personalities of leaders or candidates ... that it is the long-term factors which are usually decisive. Indeed a person's party identification will influence how he or she interprets and evaluates issues, party leaders and so on.

Campbell, Converse, Miller \& Stokes 1960, cited in Denver 2007, p 21

It is interesting to note that the party identification syndrome prevails and characterises the behaviour of an increasing proportion of Tanzania's electorate. The voters' traditional loyalties to a great extent explain their voting decisions and the percentage of votes garnered by political parties in general elections and, indeed, in opinion polls.

One of REDET's questions required respondents to divulge the name of the person they would vote for in the presidential election if it were held in March 2010. About 67 per cent of respondents intended to vote for the incumbent, President Jakaya Mrisho Kikwete, who is also chairman of the CCM. About 7 per cent of respondents named Professor Ibrahim Lipumba, chairman of the CUF, with Freeman Mbowe, the leader of CHADEMA, trailing with about 3 per cent.

In this regard we concur with the Economist Intelligence Unit (2010, p 4), which reports:

As the incumbent president, Jakaya Kikwete is eligible to serve another five-year term; the Economist Intelligence Unit still believes the most likely outcome is that the CCM will choose him as its candidate. Moreover, opinion polls show that Mr Kikwete is a strong favourite to win. This reflects the fact that he is a dynamic politician by Tanzanian standards and remains popular with the electorate. Even though we believe the most likely outcome to be Mr. Kikwete's unopposed nomination as the CCM candidate, there is a slim possibility that he will face a challenge for the nomination from within the party, which has been split by an internal rift since late 2009. Mr Kikwete is currently 
trying to tread a balance between the two factions, but if he is unable to placate them both he may face a rival for the CCM candidacy, although he should still prevail.

This implies that Mr Kikwete's personal popularity and the superior resources of the CCM will give them a considerable political advantage in the elections.

Regarding the parliamentary elections, about 39 per cent of respondents intended to vote for their current members of Parliament. However, about 61 per cent revealed that they did not intend to vote for the current legislator, implying that if elections were held in March 2010 about 61 per cent of the current members of Parliament were likely to lose their seats (REDET 2010, p 10). Support for the CCM in the polls was at higher levels than that for all the opposition parties whose support has, in fact, declined, showing that they have made no significant headway in winning voter confidence.

The local government elections held in November 2009 put the CCM in a strong position. The ruling party won 91.71 per cent compared to CUF's 3.94 per cent, CHADEMA's 2.76 per cent, the UDP's 0.43 per cent and the NCCR-M's 0.32 per cent. Eight other opposition parties obtained fewer than 50 seats each of a total of 284499 seats (PMO-RALG 2010). Taking these results into account as well as the views of voters expressed in the REDET opinion poll held in March 2010, and if the political climate remains as it is, we are in a position to predict with confidence that the CCM will win the 2010 elections on the mainland.

The concurrent elections in Zanzibar will be a closer-run contest. Whoever wins the presidency will probably find his role constrained by the requirement to work within the framework of a government of national unity (GNU) consisting of the CCM and the CUF. There is already strong support for this idea within the CUF and it seems to be growing within CCM as potentially the best way to end the long-running political tensions on the islands, which exploded into violence during the 2000 and 2005 elections. A referendum scheduled for July 2010 in Zanzibar was intended to determine whether or not the a GNU would be accepted.

\section{CONCLUSION: TYING IT ALL TOGETHER}

Elections are not a strange political phenomenon in Tanzania. The country has held them since the dawn of her independence in the context of both one-party dictatorships and competitive multiparty political systems. There was stiff competition in 1995 between the incumbent party and the opposition; free but not fair Union elections in 2000 and an aborted election in Zanzibar. In 2005 there was a considerable improvement in the management of both the Union and Zanzibari 
elections, leading both international and local observers to conclude that despite a few isolated hitches the elections had been free and fair.

Significant improvements have been made by the electoral management bodies since the last general elections in order to ensure that there are appropriate legal and institutional frameworks to facilitate the smooth conduct of elections. However, a number of significant issues remain unresolved. The electoral system in its entirety needs significant reform.

The CCM and the incumbent, President Kikwete, are still popular with the electorate. Moreover, the CCM's 'tradition' is to let the incumbent president serve two terms. Opposition parties generally lack seriousness in their preparations for the elections. Their effort and strategies to recruit 'winning' candidates are somewhat weak and non-strategic, suggesting that there will be a one-party dominated legislature and a landslide victory for the CCM's presidential candidate. This is not healthy for democracy in a multiparty political dispensation. The popularity of opposition parties in the country (apart from the CUF in Pemba) has plummeted. They need to change the way they are carrying out their political work if they are to win the confidence and trust of the electorate and must enhance their image if they are to attract more members, supporters and voters.

Little has been done in Zanzibar to create the mutually acceptable legal and institutional frameworks required for free and fair elections. The legislation governing voter registration, the role of regional and district commissioners and shehas in the electoral process, and the independence of the Zanzibar Electoral Commission are but some of the critical issues contested particularly by the CUF and which have not been resolved to the satisfaction of all election stakeholders. The mistrust between the major social forces represented by the CCM and CUF, if not objectively addressed, may dent the 2010 elections, as they have done in previous years.

Political dialogue between the president of the Revolutionary Government of Zanzibar and the secretary-general of the CUF has not only opened a new chapter in the political history of Zanzibar but also paves the way for peaceful elections there. The dialogue is perhaps the best way of ending the long-running political tensions and conflict on the islands.

A recent law enacted by the Zanzibar House of Representatives empowers the ZEC to hold a referendum on the proposal to introduce a GNU in the Isles. The unfolding events and the referendum, held on 31 July, have changed the dynamics of the political environment and have created an enabling atmosphere for peaceful, free and fair elections. Taking into account that the CUF supports a GNU, and anecdotal evidence reveals that a significant number of moderate CCM members and leaders endorse the initiative, it seems the majority of Zanzibaris will vote for such a government. The concurrent elections in Zanzibar will, by and large, be a 
close-run contest, much as they have been in the past. If a GNU is approved in the referendum, whoever wins the presidency will probably find his role constrained by the requirement to work within the framework of such a government.

In general, the current political climate, particularly the new development in Zanzibar referred to as 'maridhiano' (consensus), as well as the preparations by the election management bodies, the NEC and ZEC, suggest that grounds conducive to peaceful, free and fair elections are being cultivated and nurtured for the smooth running of the 2010 general elections in Tanzania.

\section{- REFERENCES}

Almond, A \& S Verba. 1963. The Civic Culture: Political Attitudes and Democracy in Five Nations. Princeton, NJ: Princeton University Press.

Baregu, ML\&SS Mushi. 1994. 'Mobilization, Participation and System Legitimacy'.

In R S Mukandala \& H Othman (eds). Liberalization and Politics: The 1990

Elections in Tanzania. Dar es Salaam: Dar es Salaam University Press.

Campbell, A, P Converse, W Miller \& D Stokes. 1960. The American Voter. New York: John Wiley.

Cliffe, L. 1967. One-Party Democracy. Nairobi: East Africa Publishing House.

Daily News, The, 4 May 2010.

Denver, D. 2007. Elections and Voters in Britain. New York: Palgrave Macmillan.

Economist Intelligence Unit. 2010. Country Report: Tanzania. London: Economic Intelligence Unit.

Election Support Project. 2010. 'Zanzibar Reduces Nomination Fee'. Newsletter No 6.

Farell, D M. 2001. Electoral Systems: A Comparative Introduction. New York: Palgrave.

Kiravu, R. 2010. 'Preparations for the General Elections 2010'. Paper presented at the NEC-Civil Society Organisations workshop held at Dar es Salaam International Conference Centre, Dar es Salaam.

Legal and Human Rights Centre (LHRC). 2010. A Report on the 2009 Local Government Elections. Dar es Salaam: LHRC.

Lehner, O. 2010. Election Support Project (ESP) Presentation to the Steering Committee Meeting, Dar es Salaam, 1 July 2010.

Luoga, F. 1995. 'Rule of Law and Human Rights during Transition to Democracy'. Research paper for Policy and Development Research Centre. Dar es Salaam: PDRC. 
Mmuya, M \& A Chaligha. 1992. Towards Multiparty Politics in Tanzania. Dar es Salaam: Dar es Salaam University Press.

Mukandala, R S \& H Othman (eds). Liberalization and Politics: The 1990 Elections in Tanzania. Dar es Salaam: Dar es Salaam University Press.

Mushi, S S \& R S Mukandala (eds). 1997. Multiparty Democracy in Transition: Tanzania's 1995 General Elections. Dar es Salaam: TEMCO

Mushi, S S, R S Mukandala \& M Baregu (eds). 1994. Tanzania's Political Culture: A Baseline Survey. Dar es Salaam: Dar es Salaam University Press.

Mwananchi, 10 May 2010.

National Electoral Commission (NEC). 1996. Report on the 1995 Presidential, Parliamentary and Councillors' Elections. Dar es Salaam: NEC.

_. 2001. Report on the 2000 Presidential, Parliamentary and Councillors' Elections. Dar es Salaam: NEC

- 2006. Report on the 2005 Presidential, Parliamentary and Councillors' Elections. Dar es Salaam: NEC.

_ 2010. 'The Update on Election Preparation'. Paper presented to the ESPTechnical Committee Meeting, Dar es Salaam, 1 July 2010.

Othman, H, I Bavu \& M Okema (eds). 1990. Tanzania: Democracy in Transition. Dar es Salaam: Dar es Salaam University Press.

PMO-RALG. 2010. Report on the Local Government Elections. Dar es Salaam: Government Printer.

Powell, G B. 2000. Elections as Instruments of Democracy: Majoritarian and Proportional Visions. New Haven: Yale University Press.

REDET. 2010. The $16^{\text {th }}$ Opinion Polls Report: Peoples Opinion on the 2010 General Elections. Dar es Salaam: REDET

REDET-TEMCO. 2006. The 2005 Presidential and General Elections in Zanzibar. Dar es Salaam: REDET/ TEMCO.

Revolutionary Government of Zanzibar. 1984. The Election Act, No 11 of 1984. Zanzibar: Government Printer.

TEMCO. 1997. The 1995 General Elections in Tanzania: Report of the Tanzania Election Monitoring Committee. Dar es Salaam: TEMCO.

— 2001. The 2000 General Elections in Tanzania: Report of the Tanzania Election Monitoring Committee. Dar es Salaam: TEMCO.

— 2006. The 2005 General Elections in Tanzania: Report of the Tanzania Election Monitoring Committee. Dar es Salaam: TEMCO.

UNDP-ESP. 2010a. Second Periodic Report (1st January - 31st March 2010). Dar es Salaam: UNDP/ESP.

UNDP-ESP. 2010b. 'Election Support Project'. Newsletter No. 5. Dar es Salaam: UNDP/ESP. 
United Republic of Tanzania. 1979. Local Government Authorities (Elections) Act, 1979. Dar es Salaam: Government Printer.

—_. 1991. Tume ya Rais ya Mfumo wa Chama Kimoja au Vyama Vingi oya Siasa Tanzania. Dar es Salaam: Government Printer.

_- 2008. Voter Education Strategic Plan 2008-2010. Dar es Salaam: National Electoral Commission (NEC).

- 2009. Electoral laws (Miscellaneous Amendments) Act, 2009. Dar es Salaam: Government Printer.

_. 2010. Elections Expenses Act, 2010 (Act No. 6 of 2010). Dar es Salaam: Government Printer. 